\title{
Hormigones con cementos compuestos ternarios. Parte II: Mecanismos de transporte
}

\author{
Ternary blend cements concrete. \\ Part II: Transport mechanism
}

\author{
G. Menéndez ${ }^{(*)}, \underline{\text { V. L. Bonavetti }}{ }^{(*)}$ y E. F. Irassar ${ }^{(*)}$
}

Recepción/Received: 20-X-05

Aceptación/Accepted: 3-V-06

\section{RESUMEN}

En la actualidad con la utilización de cementos con dos o más adiciones (cementos compuestos) predecir la durabilidad del hormigón a partir sólo de su resistencia conduce a cometer errores que pueden afectar la vida útil de las construcciones de hormigón. Pues es bien conocido que se pueden elaborar hormigones de una misma clase resistente con distintos materiales y proporciones, que podrán presentar un comportamiento durable totalmente diferente. En este trabajo se evalúa la absorción de agua, la capacidad de absorción, la absorción inicial superficial de hormigones elaborados con cemento Portland sin adición, cementos compuestos binario (caliza) y ternario (escoria granulada y caliza).

Palabras clave: cementos con adiciones, caliza, escorias granuladas de alto horno, absorción, capacidad de absorción.

\section{SUMMARY}

With today's extensive use of cements containing two or more additions (blended cements), predicting concrete durability on the grounds of its strength alone leads to errors that may affect the service life of the resulting structures. Indeed, concrete of a given strength class can be made from different materials and proportions of widely varying durability. The present study evaluated water absorption, sorptivity and initial surface absorption in concrete made with unadditioned Portland, binary (limestone) and ternary (limestone and granulated slag) blend cement.

Keywords: blend cements, limestone, granulated blast furnace slag, water absorption, sorptivity.

\section{INTRODUCCIÓN}

En general la calidad de un hormigón es juzgada por medio de su resistencia a compresión en probetas curadas adecuadamente y a una determinada edad. El valor de la resistencia a compresión a 28 días ha sido y continúa siendo considerado como uno de los criterios más convenientes para asegurar la calidad y aceptación final del hormigón.

\section{INTRODUCTION}

Concrete quality is generally judged on the grounds of the strength of duly cured specimens of a pre-defined age. Twenty-eight day compressive strength has been and continues to be regarded to be one of the most suitable criteria for the assurance and acceptance of concrete quality. This is a very popular practice

\footnotetext{
(*) Universidad Nacional del Centro, Olavarria (Argentina).
}

Persona de contacto / Corresponding author: vbonavet@fio.unicen.edu.ar 
Esta práctica es muy popular debido a que la medición de la resistencia del hormigón es lo suficientemente sencilla, en relación con la cuantificación de otros parámetros. Adicionalmente, con los cementos que se producían hace algunos años existía una buena correlación entre la resistencia y la durabilidad del hormigón, pero con la incorporación de adiciones y la modificación en la composición y finura del clínker esta analogía dejó de ser correcta. Motivo por el cual, especificar la durabilidad del hormigón en forma indirecta por medio de sus parámetros resistentes, sin poseer un entendimiento claro sobre los mecanismos de transporte y los procesos de deterioro, resulta insuficiente en la mayoría de los casos. Más aún, teniendo en cuenta que se pueden elaborar hormigones de una misma clase resistente con distintos materiales y proporciones muy variables, y con un comportamiento durable totalmente diferente (1).

Por otra parte, es cada vez más común la inclusión de materiales suplementarios provenientes de recursos naturales (puzolanas, caliza) o subproductos de otras industrias (ceniza volante, humo de sílice, escorias, etc.) para la elaboración de cementos ternarios. En este tipo de cemento, normalmente se desconoce la composición del clínker y el tipo y la proporción de las adiciones que lo componen. También, se ignora cómo es afectada la porosidad y la estructura de poros y, en consecuencia, es difícil predecir el comportamiento durable de estos materiales.

La porosidad y la estructura de poros de la pasta de cemento ejerce el mayor control sobre el ingreso de sustancias potencialmente agresivas (2). Se ha encontrado que la estructura de poros y la alcalinidad de la zona cercana a la superficie del hormigón (hormigón de recubrimiento) son las propiedades que afectan en mayor medida la durabilidad de las estructuras. Estos parámetros pueden ser estimados por medio de los ensayos de capacidad de absorción y carbonatación, respectivamente. Pero, como la carbonatación se torna irrelevante para hormigones con capacidad de absorción nula (1), la velocidad de absorción y la cantidad de agua absorbida asumen vital importancia al momento de caracterizar la durabilidad de los hormigones.

En este trabajo se analiza la influencia de la incorporación al cemento de escoria granulada de alto horno y caliza sobre la absorción de los hormigones con cementos compuestos binarios y ternarios.

\section{PARTE EXPERIMENTAL}

Materiales: para el programa de ensayos se utilizó un cemento Portland sin adición ( $C P N$ ) con un $58 \%$ de $\mathrm{C}_{3} \mathrm{~S}$ y $2 \%$ de $\mathrm{C}_{3} \mathrm{~A}$ y dos cementos Portland con caliza ( $C P 12 \mathrm{~F}$ y $C P 18 F)$. Los cementos tienen una resistencia a compresión a 28 días de 45, 39 y $39 \mathrm{MPa}$, con una superficie específica de 321,380 y $383 \mathrm{~m}^{2} / \mathrm{kg}$ para contenidos de caliza de because concrete strength can be quantified far more simply than other properties. While in the cements normally used up until a few years ago there was a close correlation between concrete strength and durability, the inclusion of additions and the changes introduced in clinker composition and fineness have since distorted this analogy. As a result, specifying concrete durability indirectly in terms of its strength without a clear understanding of transport mechanisms and deterioration processes is insufficient in most cases, considering that concrete of a given strength class can be made with different materials and proportions of widely varying durability (1).

At the same time, natural materials (pozzolans, limestone) and industrial by-products (fly ash, silica fume, slag and so on) are being used more and more frequently as supplements in the manufacture of ternary cements. And clinker composition and addition type and proportion are seldom known in such products. Predicting the durability of these materials is no easy task under such conditions, particularly in light of the lack of information on porosity and pore structure.

The two properties that primarily control the influx of potentially aggressive substances (2). Durability, moreover, has been shown to be affected more intensely by pore structure and alkalinity on and around the concrete surface than any other feature of concrete. These two parameters can be estimated by sorptivity and carbonation tests, respectively. But inasmuch as carbonation is irrelevant in concretes with nil sorptivity (1), the absorption rate and the amount of water absorbed are of vital importance in the characterization of concrete durability.

The present study analyzes the effect on concrete absorption of adding granulated blast furnace slag and limestone to the cement used in its manufacture.

\section{EXPERIMENTAL}

Materials: the test protocol called for an unadditioned Portland cement (CPN) containing 58\% $C_{3} S$ and $2 \%$ $C_{3} A$, as well as two limestone-Portland blended cements (CP12F and CP18F). The 28-day compressive strength of the cements with 0,12 and $18 \%$ limestone was, respectively, 45, 39 and $39 \mathrm{MPa}$, and their $\mathrm{BET}$ specific 
0,12 y $18 \%$, respectivamente. La escoria granulada de alto horno se adicionó en peso del cemento teniendo la misma un módulo químico de $(C+M+A / S)$ de 1,8 . El árido grueso utilizado fue piedra de machaqueo granítica con un tamaño máximo de $19 \mathrm{~mm}$ y el árido fino fue una arena natural silícea con módulo de finura de 2,35.

Proporciones de las mezclas: con los materiales antes descriptos se elaboraron hormigones con $350 \mathrm{~kg} / \mathrm{m}^{3}$ de material cementante, relación agua/material cementante $(a / m c)$ de 0,50 , relación árido fino/árido total de 0,45 y asentamiento de $100 \pm 20 \mathrm{~mm}$. El curado de las probetas fue de 24 horas en el molde y tras ser desmoldadas se sumergieron en agua saturada con cal hasta la edad de ensayo $(3,7,28,90$ y 360 días).

Todos los hormigones estudiados presentaron una adecuada trabajabilidad, buena terminación y cohesión, con capacidades y velocidades de exudación decrecientes a medida que aumenta el contenido de caliza en el cemento compuesto. Adicionalmente, los hormigones registraron una resistencia a compresión de $26,7 \pm 2,3 \mathrm{MPa}, 35,5 \pm 1,0$ MPa y $40,0 \pm 1,9 \mathrm{MPa}$, a 7, 28 y 360 días. Los resultados obtenidos en estado fresco y en estado endurecido se encuentran detallados en una publicación previa (3).

Absorción de agua: este parámetro se evaluó como la ganancia de peso de los prisma s $\left(10 \times 15 \times 15 \mathrm{~cm}^{3}\right)$ después de 48 horas de inmersión total en agua de acuerdo a la norma ASTM C 642.

Absorción inicial superficial: la absorción inicial superficial se evaluó sobre probetas prismáticas de $10 \times 15 \times$ $15 \mathrm{~cm}^{3}$ de acuerdo al método ISAT-10 definido por la norma BS 1881.

Capacidad de absorción: para la realización de este ensayo $(2,4)$ se utilizaron prismas de $10 \times 15 \times 15 \mathrm{~cm}^{3}$ que fueron curados en agua saturada con cal a $20 \pm 2{ }^{\circ} \mathrm{C}$. Cumplida la edad de ensayo, los prismas se sometieron a un secado en estufa a $105 \pm 5^{\circ} \mathrm{C}$ durante 24 horas y luego se pintaron con epoxi dejando un área sin pintar de $100 \mathrm{~cm}^{2}$ sobre la cara de moldeo. El criterio usado para el análisis de la velocidad de absorción fue la cantidad de agua absorbida medida por la ganancia de masa a 1, 5, 10, 15, 30, 60, 120, $240,360,720,1.440$ y 2.880 minutos utilizando una balanza. Con los resultados obtenidos en el ensayo se calculó la capacidad de absorción (S), a partir de la gráfica de agua absorbida en función de la raíz cuadrada del tiempo (5).

Modelo de estudio: para la modelización de los hormigones en base a su absorción se utilizó el diseño de mezclas denominado Simplex (6), considerando como variables a los tres componentes del sistema: cemento Portland, caliza y escoria. Con los valores de absorción de cada uno de los siete puntos que conforman el diseño experimental y el surface was 321,380 and $383 \mathrm{~m}^{2} / \mathrm{kg}$. Granulated blast furnace slag with a $(C+M+A / S)$ chemical modulus of 1.8 was added by weight of cement. Crushed granite with a maximum particle size of $19 \mathrm{~mm}$ was used as the coarse aggregate, while the fines consisted in natural siliceous sand with a fineness modulus of 2.35 .

Mixture proportions: the above materials were used to manufacture concrete with $350 \mathrm{~kg} / \mathrm{m}^{3}$ of cementitious material, a water/cementitious material $(w / \mathrm{cm})$ ratio of 0.50 , a fine/coarse aggregate ratio of 0.45 and a plastic slump of $100 \pm 20 \mathrm{~mm}$. Specimens were cured in moulds for 24 hours and then immersed after demoulding in lime-saturated water until reaching the test age $(3,7$, 28, 90 and 360 days).

The concretes studied exhibited suitable workability, finish and cohesion, while bleeding and bleeding rates in these materials declined with increasing limestone content. The concretes had 7-, 28- and 360-day compressive strengths of $26.7 \pm 2.3 \mathrm{MPa}$. $35.5 \pm 1.0 \mathrm{MPa}$ and $40.0 \pm 1.9 \mathrm{MPa}$ (the results obtained for the fresh mix and hardened concrete are given in a prior paper (3)).

Water absorption: this parameter was determined as specified in standard ASTM C 642, i.e., measuring (10 x $15 \times 15-\mathrm{cm})$ prism weight gain after 48 hours of total immersion in water.

Initial surface absorption: initial surface absorption was found for $10 \times 15 \times 15-\mathrm{cm}^{3}$ prismatic specimens with the ISAT 10 method described in standard BS 1881.

Sorptivity: this trial $(2,4)$ was conducted on $10 \times 15 \times$ $15-\mathrm{cm}^{3}$ specimens cured in lime-saturated water at $20 \pm$ $2{ }^{\circ} \mathrm{C}$. After the trial age specimens were oven-dried at $105 \pm 5^{\circ} \mathrm{C}$ for 24 hours, the entire surface was coated with epoxy paint except for one patch measuring 100 $\mathrm{cm}^{2}$. The criterion used to analyze the absorption rate was the amount of water absorbed, defined to be weight gain after immersion, measured on a scales at $t=1,5$, $10,15,30,60,120,240,360,720,1440$ and 2880 minutes. The results obtained were used to plot an amount of water absorbed vs square root of time graph, from which sorptivity (S) was calculated (5).

Model: simplex (6) mixture design was used to model the concrete absorption, in which the variables were the three system components: Portland cement, limestone and slag. The expression relating absorption to the set of variables for each age studied was determined from the seven absorption values comprising the experimental 
punto de ajuste del modelo (CP12F) (Figura 1), se determinó la expresión que relaciona este parámetro con el conjunto de variables para cada edad estudiada. La ecuación del modelo está dada por la expresión [1]: design and the model fitting point (CP12F) (Figure 1). The model is represented by equation [1].

$$
Y_{(n)}=a X_{1}+b X_{2}+c X_{3}+d X_{1} X_{2}+e X_{1} X_{3}+f X_{2} X_{3}+g X_{1} X_{2} X_{3}
$$

donde: $Y_{(\mathrm{n})}$ es la absorción a la edad de $n$ días, $X_{1}$ es el porcentaje de caliza, $X_{2}$ es el porcentaje de escoria, $X_{3}$ es el porcentaje de cemento Portland, y $a, b, c, d, e, f$ y $g$ son los coeficientes del sistema obtenidos usando el método de mínimos cuadrados. Los valores de capacidad de absorción y absorción inicial superficial obtenidos a partir de la expresión anterior no difirieron en más del 5 y $6 \%$ con respecto a los resultados experimentales, respectivamente.

\section{RESULTADOS}

Absorción de agua: todos los valores de la absorción de agua de los hormigones elaborados con cemento binario y ternario se hallan comprendidos entre 5,6 a $2 \%$ y 5,8 a $2 \%$, respectivamente. La Figura 2 a muestra que para todas las edades la absorción del hormigón con $C P 12 F$ es menor al correspondiente del hormigón con $C P N$, mientras que para el hormigón con $C P 18 F$ después de 28 días este parámetro es superior. Contrariamente, hasta los 7 días el hormigón con $C P N+20 E$ presenta una absorción de agua mayor al hormigón con $C P N$, mientras que a 360 días registra la menor absorción de todos los hormigones elaborados con cemento binario, resultando su valor $22 \%$ menor al registrado por el hormigón con CPN. where: $Y_{(n)}$ is absorption at age $n$ (in days), $X_{1}$ is the percentage of limestone, $X_{2}$ the percentage of slag, $x_{3}$ the percentage of Portland cement, and $a, b, c, d, e, f$, and $g$ the system coefficients found with the minimum squares method. The sorptivity and initial surface absorption values obtained from the above expression differed from the experimental results by less than $5 \%$ and $6 \%$, respectively.

\section{RESULTS}

Water absorption: all the water absorption values for concrete made with binary and ternary cements ranged from 5.6 to $2 \%$ and 5.8 to $2 \%$, respectively. Figure $2 a$ shows that absorption was lower in CP12F concrete than in CPN concrete for all ages, but higher in CP18F than in $C P N$ concrete after 28 days. Conversely, CPN+20E concrete exhibited higher water absorption than CPN concrete up to $t=$ seven days, while after 360 days it had the lowest absorption of all the concretes made with binary cement, with a value $22 \%$ lower than recorded for CPN concrete.

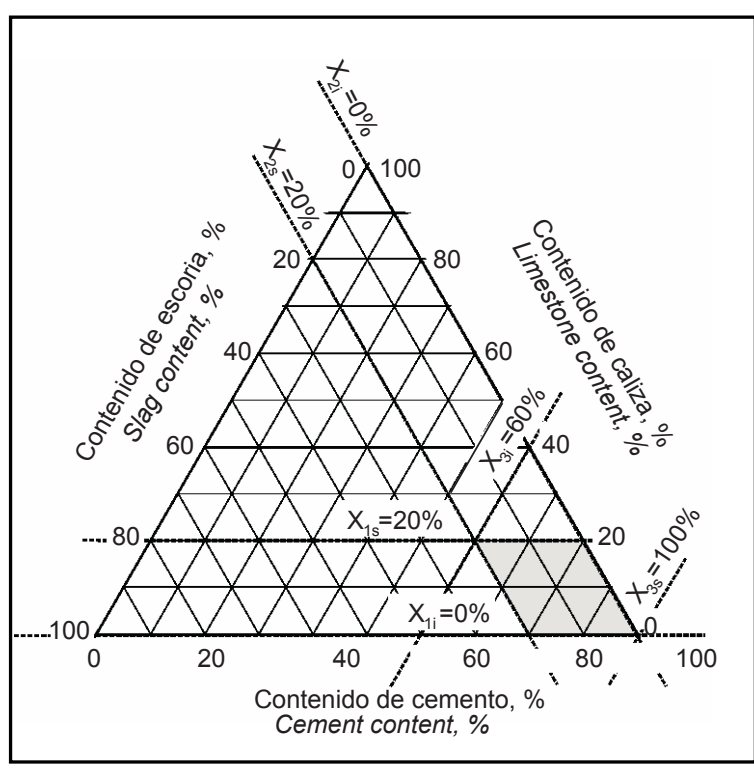

Figura 1. Dominio del diseño experimental. Figure 1. Experimental design domain. 
La absorción de agua de los hormigones elaborados con cemento compuesto ternario se presenta en la Figura $2 \mathrm{~b}$. En la misma se observa que la absorción de agua de todos los hormigones resulta similar a la obtenida por el hormigón con CPN hasta los 28 días, sin embargo, a partir de esta edad los hormigones con cementos ternarios registran valores de absorción entre 15 y $27 \%$ menores a la alcanzada por el hormigón con CPN.

Por último, este ensayo es muy útil para evaluar la porosidad abierta del hormigón (red de poros interconectados que permite el paso y circulación de los fluidos), no obstante, no puede emplearse para determinar la velocidad de absorción, debido a que en este ensayo el agua ingresa hacia el interior de la masa de hormigón desde todas las caras de la probeta. En virtud de ello, si se desea analizar la absorción en la zona de recubrimiento de la estructura, o bien la velocidad a la que ingresa el agua a la misma, debe recurrirse a ensayos del tipo ISAT 10 o capacidad de absorción, respectivamente.

Absorción inicial superficial: la Figura 3 muestra las curvas de isorrespuesta de la absorción superficial obtenidas por el ensayo ISAT 10, a 3, 7, 28, 90 y 360 días. En la misma se puede observar que a 3 días (Figura $3 a$ ), la mínima absorción es registrada para valores de $X_{1}=$ $10 \%$ y $X_{2}=0 \%\left(112,5 \times 10^{-2} \mathrm{ml} / \mathrm{m}^{2} \mathrm{~s}\right)$, mientras que valores menores a los obtenidos por el hormigón con CPN $\left(127,4 \times 10^{-2} \mathrm{ml} / \mathrm{m}^{2} \mathrm{~s}\right)$ pueden alcanzarse con hasta $17,5 \%$ de $X_{1}$ y $20 \%$ de $X_{2}$. La forma de las isorrespuestas evidencia una clara dependencia de la absorción con respecto al contenido de caliza.

A 7 días (Figura 3b), la mínima absorción corresponde al punto $X_{1}=10 \%$ y $X_{2}=0 \%\left(105,2 \times 10^{-2} \mathrm{ml} / \mathrm{m}^{2} \mathrm{~s}\right)$. No obstante, existe un área del dominio donde los valores de absorción son menores al registrado por el hormigón con $C P N\left(112,5 \times 10^{-2} \mathrm{ml} / \mathrm{m}^{2} \mathrm{~s}\right)$ y en el cual la combinación punto $X_{1}=10 \%$ y $X_{2}=10 \%$ representa la mezcla con

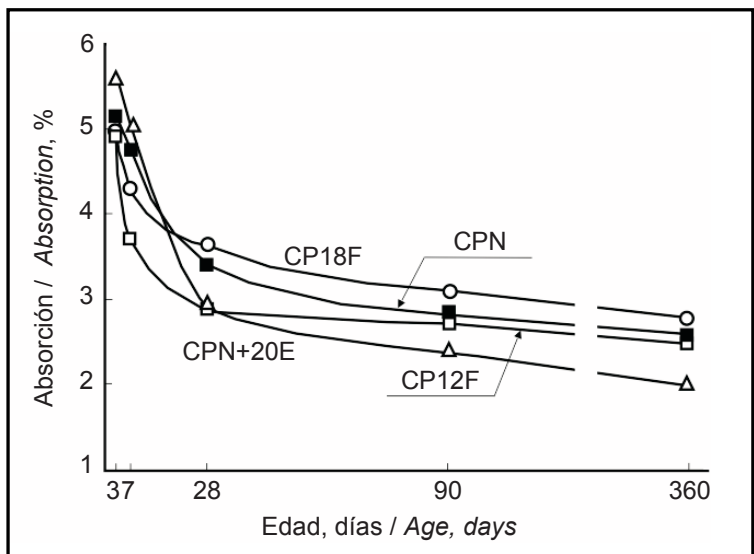

Water absorption in ternary blend concretes is given in Figure $2 b$. Up to 28 days, water absorption in all the concretes was similar to the value found for CPN concrete; after that time the ternary cement concretes exhibited absorption values from 15 to $27 \%$ lower than CPN concrete.

Lastly, this trial proved to be very useful for evaluating concrete open porosity (network of interconnected pores across which fluids can circulate). It cannot, however, be used to determine the absorption rate, for in this test the water flows into the concrete from all sides of the specimen. Consequently, ISAT 10 or sorptivity tests must be conducted to analyze concrete cover absorption or absorption rate, respectively.

Initial surface absorption: Figure 3 shows the surface absorption iso-response contours obtained with the ISAT 10 test at the ages of 3, 7, 28, 90 and 360 days. Threeday minimum absorption (Figure 3a) was recorded for values of $X_{1}=10 \%$ and $X_{2}=0 \%\left(112.5 \times 10^{-2} \mathrm{ml} / \mathrm{m}^{2} \mathrm{~s}\right)$, although absorption values lower than recorded for CPN concrete $\left(127.4 \times 10^{-2} \mathrm{ml} / \mathrm{m}^{2} \mathrm{~s}\right)$ could be attained with $X_{1}$ of up to $17.5 \%$ and $X_{2}$ up to $20 \%$. The form of the isoresponse contours shows absorption to be clearly dependent on limestone content.

The seven-day absorption minimum (Figure $3 b$ ) was located at point $X_{1}=10 \%$ and $X_{2}=0 \%\left(105.2 \times 10^{-2}\right.$ $\left.\mathrm{ml} / \mathrm{m}^{2} \mathrm{~s}\right)$. The point $X_{1}=10 \%$ and $X_{2}=10 \%$ represented the mix combination with the highest addition (or lowest clinker) content with which absorption values lower than recorded for CPN concrete $\left(112.5 \times 10^{-2} \mathrm{ml} / \mathrm{m}^{2} \mathrm{~s}\right)$

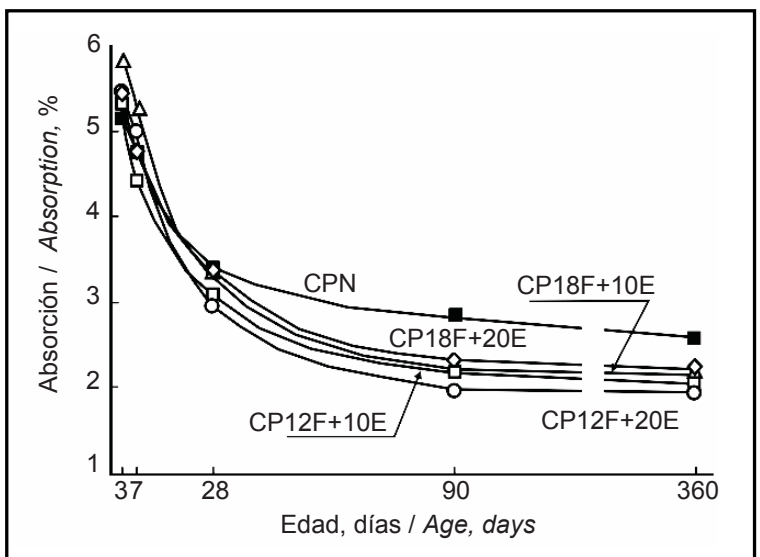

Figura 2. Absorción de agua de los hormigones con cementos compuestos: a) binarios y b) ternarios. Figure 2. Water absorption in concrete made with blended cements: a) binary and b) ternary. 
mayor contenido de adición (o menor contenido de clínker). A 28 días (Figura 3c), el menor valor de absorción es registrado para $X_{1}=3 \%$ y $X_{2}=10 \%$, además, puede observarse que para valores de $X_{1}$ entre 0 y $17,5 \%$ no existen cambios apreciables en la absorción superficial del cemento compuesto binario, pues este parámetro queda comprendido en la zona $73-77 \times 10^{-2} \mathrm{ml} / \mathrm{m}^{2} \mathrm{~s}$, mientras que con valores de $X_{2}$ entre 5 y $15 \%$ se registran las menores absorciones para el cemento compuesto binario con escoria ( $<65 \times 10^{-2} \mathrm{ml} / \mathrm{m}^{2} \mathrm{~s}$ ).

El área que corresponde a la mínima absorción a 90 días presenta un corrimiento hacia el centro del dominio y queda totalmente comprendida dentro de éste (Figura $3 d)$. A esta edad, valores de $X_{1}>15 \%$ penalizan el comportamiento del hormigón frente al parámetro estudiado, no obstante, existe una amplia gama de combinaciones para obtener valores de absorción menores a la obtenida por el hormigón con CPN (<64,6 x 10-2 $\left.\mathrm{ml} / \mathrm{m}^{2} \mathrm{~s}\right)$. A 360 días, el punto de menor absorción queda determinado en $X_{1}=10 \%$ y $X_{2}=10 \%$, aun así los hormigones con cementos ternarios con valores de $X_{1}$ entre 5 y $15 \%$ y $X_{2}$ entre 3 y $17,5 \%$ registran una menor absorción superficial que el hormigón con CPN (Figura 3e).

Por último, Dhir et al. (7) han propuesto un esquema de clasificación de la durabilidad del hormigón basado en el valor de ISAT 10 (Tabla 1). En esta Tabla se puede observar que a 90 días la mayoría de los hormigones se encuentra dentro de la escala $2\left(51-70 \times 10^{-2} \mathrm{ml} / \mathrm{m}^{2} \mathrm{~s}\right)$, en consecuencia, es de esperar que a esta edad todos los hormigones tengan similar comportamiento frente a la difusión de cloruros y a la carbonatación.

Capacidad de absorción: la Figura 4 presenta las curvas de isorrespuestas de la capacidad de absorción a 3, 7, 28, 90 y 360 días. La capacidad de absorción de un hormigón define la velocidad con que el mismo puede llegar a ser penetrado a través del mecanismo de absorción capilar, en consecuencia, el mejor comportamiento implica un mínimo en las curvas de isorrespuestas. A 3 días, could be attained. After 28 days (Figure 3c), the lowest absorption value was recorded for $X_{1}=3 \%$ and $X_{2}=10 \%$. Moreover, no perceptible changes were found in the surface absorption of the binary blended cement for $X_{1}$ values of from 0 to $17.5 \%$, in which zone this parameter remained in the $73-77 \times 10^{-2} \mathrm{ml} / \mathrm{m}^{2} \mathrm{~s}$ range. Absorption was lowest for slag-containing binary cement $\left(<65 \times 10^{-2} \mathrm{ml} / \mathrm{m}^{2} \mathrm{~s}\right)$, in turn, at $X_{2}$ values of from 5 to $15 \%$.

In 90-day specimens, the absorption minimum shifted toward and was contained entirely within the centre of the domain (Figure 3d). At this age, values of $X_{1}>$ $15 \%$ had an adverse effect on concrete performance in terms of the parameter studied, although absorption values smaller than recorded for CPN concrete $\left(<64.6 \times 10^{-2} \mathrm{ml} / \mathrm{m}^{2} \mathrm{~s}\right)$ could be obtained across a wide range of $X_{1}-X_{2}$ combinations. At 360 days, the lowest absorption point was found at $X_{1}=10 \%$ and $X_{2}=10 \%$, while ternary cement concretes with $X_{1}$ values of from 5 to $15 \%$ and $X_{2}$ values ranging from 3 to $17.5 \%$ exhibited lower surface absorption than CPN concrete (Figure 3e).

Lastly, Dhir et al. (7) proposed a scheme for classifying concrete durability based on the ISAT 10 value (Table 1). As the table shows, at 90 days most of the concretes fell within the category 2 range (51-70 $\times 10^{-2}$ $\left.\mathrm{ml} / \mathrm{m}^{2} \mathrm{~s}\right)$; consequently, all these concretes would be expected to exhibit similar chloride diffusion and carbonation behaviour.

Sorptivity: iso-response contours for 3-, 7-, 28-, 90- and 360-day sorptivity are given in Figure 4. Since concrete sorptivity defines the rate of penetration due to capillary absorption, the lowest values on the iso-response contours are indicative of the highest performance. The three-day sorptivity minimum, which corresponded to $X_{1}=10 \%$ and $X_{2}=5 \%\left(0.19 \mathrm{~g} / \mathrm{cm}^{2} \mathrm{~h}^{1 / 2}\right)$, was $13 \%$ lower than the

Tabla 1 / Table 1

Esquema de clasificación de la durabilidad (9)

Durability classification scheme (9)

\begin{tabular}{|c|c|c|}
\hline $\begin{array}{c}\text { Escala de durabilidad } \\
\text { Category }\end{array}$ & ISAT $10\left(\times 10^{-2} \mathrm{ml} / \mathrm{m}^{2} \mathrm{~s}\right)$ & $\begin{array}{l}\text { Consideraciones adicionales } \\
\text { Comments }\end{array}$ \\
\hline 1 & $<50$ & Difusión de cloruros / Chloride diffusion \\
\hline 2 & $51-70$ & $\begin{array}{l}\text { Con cenizas volantes o escorias, incrementa la escala por dos clases } \\
\text { Two categories higher with fly ash or slag }\end{array}$ \\
\hline 3 & $71-90$ & Carbonatación / Carbonation \\
\hline 4 & $91-100$ & $\begin{array}{l}\text { Con cenizas volantes o escorias, disminuye una clase } \\
\text { One category lower with fly ash or slag }\end{array}$ \\
\hline \multirow[t]{2}{*}{5} & $>100$ & Resistencia al congelamiento / Freeze resistance \\
\hline & & Con cenizas volantes, disminuye una clase / One category lower with fly ash \\
\hline
\end{tabular}




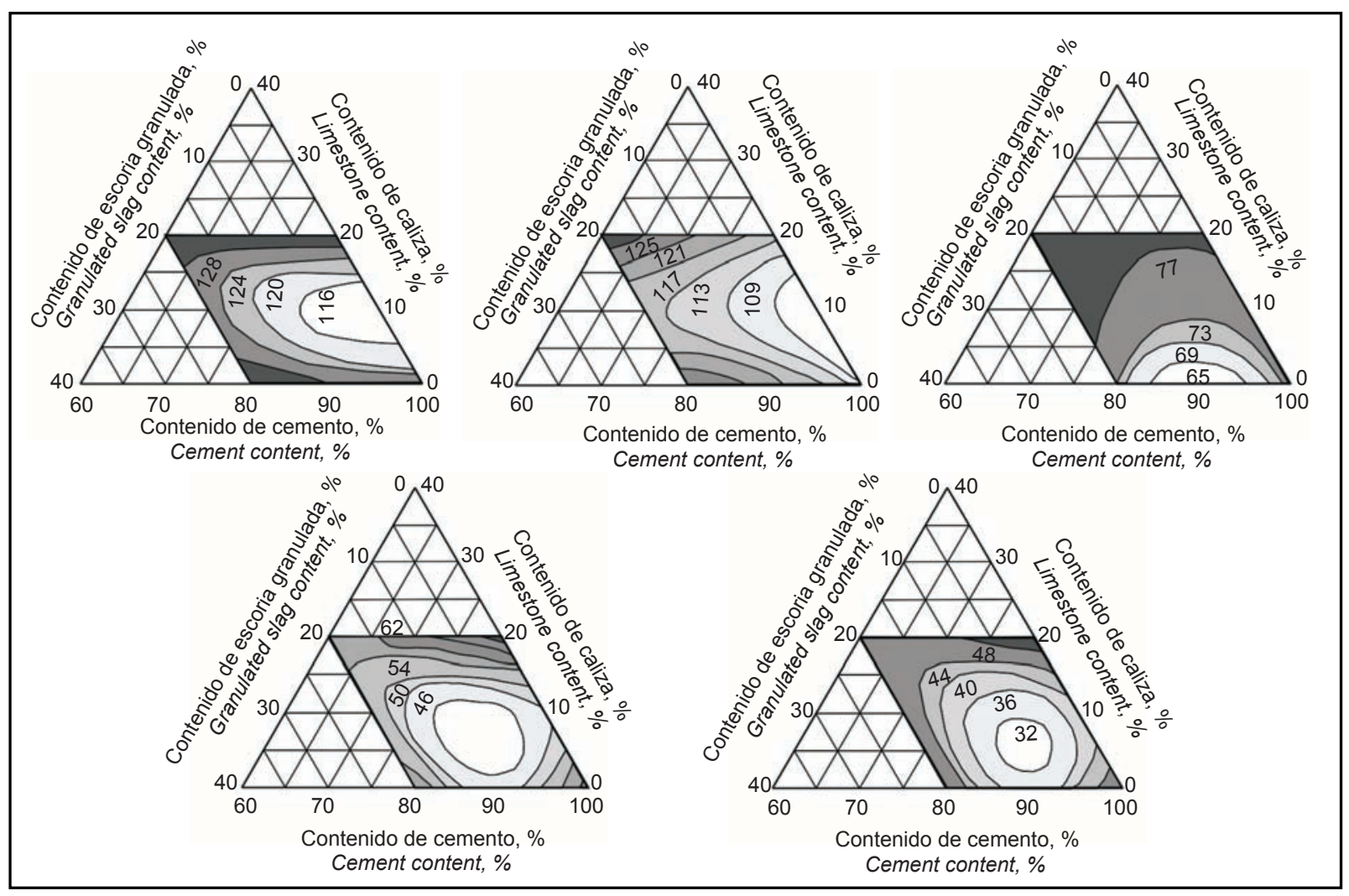

Figura 3. Curvas de isorrespuesta de la absorción inicial superficial $\left(\times 10^{-2} \mathrm{ml} / \mathrm{m}^{2} \mathrm{~s}\right)$, determinadas por el ensayo ISAT 10: a) 3 días, b) 7 días, c) 28 días, d) 90 días y e) 360 días.

Figure 3. Initial surface absorption $\left(\times 10^{-2} \mathrm{ml} / \mathrm{m}^{2} \mathrm{~s}\right.$ ) iso-response contours found with the ISAT 10 test at a) 3 days, b) 7 days, c) 28 days, d) 90 days and e) 360 days.

es posible observar que la mínima absorción está dada para valores de $X_{1}=10 \%$ y $X_{2}=5 \%\left(0,19 \mathrm{~g} / \mathrm{cm}^{2} \mathrm{~h}^{1 / 2}\right)$, resultando $13 \%$ menor a la obtenida por el hormigón con CPN (Figura 4a). Sin embargo, existe una amplia combinación de valores de $X_{1}$ (2 a 15\%) y $X_{2}$ (0 a $15 \%$ ) que permiten obtener una capacidad de absorción menor a la registrada por el hormigón con $C P N$. La mínima capacidad de absorción a 7 días (Figura 4b), está dada para el valores de $\mathrm{X}_{1}=\mathrm{X}_{2}=8 \%\left(0,109 \mathrm{~g} / \mathrm{cm}^{2} \mathrm{~h}^{1 / 2}\right)$, resultando $39 \%$ menor a la correspondiente al hormigón con CPN. Sin embargo, con la combinación $X_{1}=17,5 \%$ y $X_{2}$ $=15 \%$ se alcanza el mayor contenido de adiciones $\sin$ superar la absorción del hormigón con CPN.

A 28 días, las curvas de isorrespuestas muestran que la capacidad de absorción de los hormigones depende casi exclusivamente del nivel adoptado por $X_{1}$ (Figura 4c). La menor tasa de absorción se obtiene para valores de $X_{1}=0$ y $X_{2}=10 \%$, no obstante, la zona delimitada por la curva de $0,10-0,08 \mathrm{~g} / \mathrm{cm}^{2} \mathrm{~h}^{1 / 2}$ permite elaborar hormigones con contenidos de $X_{1}<10 \%$ y $X_{2}<10 \%$ con un comportamiento similar al registrado por el hormigón con CPN. La zona de mínima respuesta a 90 días (Figura 4d) se traslada hacia los niveles más elevados de $X_{2}$, donde el punto de
CPN concrete figure (Figure 4a). Sorptivity was nonetheless lower than in CPN concrete over a wide range of combinations of $X_{1}$ (2 to 15\%) and $X_{2}$ ( 0 to $15 \%$ ) values. Minimum seven-day sorptivity (Figure $4 \mathrm{~b})$, found for values of $X_{1}=X_{2}=8 \%\left(0.109 \mathrm{~g} / \mathrm{cm}^{2} h^{1 / 2}\right)$, was $39 \%$ lower than the CPN concrete figure. The highest addition content at which sorptivity was no higher than in CPN concrete was the combination $X_{1}=17.5 \%$ and $X_{2}=15 \%$.

The 28-day iso-response contours showed that concrete sorptivity depended nearly exclusively on the level of $X_{1}$ adopted (Figure $4 c$ ). The lowest absorption rate was found for values of $X_{1}=0$ and $X_{2}=10 \%$, although within the area delimited by the $0.10-0.08 \mathrm{~g} / \mathrm{cm}^{2} \mathrm{~h}^{1 / 2}$ contour the performance of concretes with $X_{1}<10 \%$ and $X_{2}<10 \%$ was similar to the behaviour recorded for CPN concrete. The 90-day minimum response zone (Figure 4d) shifted toward higher $X_{2}$ values, with the lowest absorption point found at $X_{1}=13$ and $X_{2}=20 \%\left(0.05 \mathrm{~g} / \mathrm{cm}^{2} \mathrm{~h}^{1 / 2}\right)$. 
menor absorción corresponde a $X_{1}=13$ y $X_{2}=20 \%(0,05$ $\mathrm{g} / \mathrm{cm}^{2} \mathrm{~h}^{1 / 2}$ ). No obstante, es posible elaborar hormigones con absorciones menores o iguales a la alcanzada por el hormigón con CPN con hasta $20 \%$ de $X_{1}$ y $20 \%$ de $X_{2}$. A 360 días, la Figura 4e muestra el punto $X_{1}=10$ y $X_{2}=20 \%$ registra la menor capacidad de absorción. Este punto experimental posee una tasa de absorción $42 \%$ menor que la correspondiente al hormigón con CPN. Aun así todos los hormigones estudiados poseen una capacidad menor $\mathrm{O}$ similar a la registrada por el hormigón con CPN.

De acuerdo a Martys y Ferraris (4), el ensayo de capacidad de absorción no alcanza por sí solo para predecir la vida en servicio de las estructuras, pues en este método la velocidad de absorción está influenciada en forma considerable por el grado de saturación del hormigón, y además, no tiene en cuenta que el mismo pueda estar expuesto a ciclos de mojado y secado. A pesar de esto, otros autores como Ho et al. (8) han sugerido que, en las construcciones durables, el valor de la capacidad de absorción debe ser menor a $0,6 \mathrm{~cm} / \mathrm{h}^{1 / 2}$. Este valor considera que en un periodo de lluvias de 24 horas, el agua puede penetrar cerca de $30 \mathrm{~mm}$ dentro del hormigón, atravesando el recubrimiento de las armaduras. Una lluvia de 24 horas, aunque es algo infrecuente, podría suceder en algunos lugares, con lo cual los hormigones con esta capacidad de absorción serían susceptibles de sufrir corrosión en el acero de refuerzo. Por este motivo, los autores recomiendan introducir un factor de seguridad de 2 y para el diseño por durabilidad del hormigón especificar una capacidad de absorción menor a $0,3 \mathrm{~cm} / \mathrm{h}^{1 / 2}$. Asumiendo que el frente de penetración medio de $0,3 \mathrm{~cm} / \mathrm{h}^{1 / 2}$ es igual a $0,3 \mathrm{~g} / \mathrm{cm}^{2} \mathrm{~h}^{1 / 2}$, es posible concluir que todos los hormigones pertenecientes al dominio estudiado, desde los 3 días de curado, presentan valores de capacidad de absorción menores al límite estipulado por Ho et al.

Sin embargo, este comportamiento se modifica cuando se produce la interrupción temprana del curado húmedo. La Tabla 2 muestra la capacidad de absorción a 28 días de los hormigones elaborados con cementos compuestos ternarios relativa al hormigón con curado húmedo continuo (28 días).
Nonetheless, concretes made with up to $20 \% X_{1}$ and $20 \% X_{2}$ exhibited sorptivity values less than or equal to the value recorded for CPN concrete. Figure $4 e$ shows that at 360 days the lowest sorptivity was at point $X_{1}=$ 10 and $X_{2}=20 \%$. The absorption rate at this point was $42 \%$ lower than in CPN concrete. In any event, in all the concretes studied sorptivity was lower than or similar to the values recorded for CPN concrete.

According to Martys and Ferraris (4), the sorptivity test does not in itself suffice to predict the service life of a structure, for in this method the absorption rate is impacted by the degree of concrete saturation, while no account is taken of the possible exposure of the concrete to wet-dry cycles. That notwithstanding, other authors such as Ho et al. (8) have suggested that for a structure to be regarded to be durable, sorptivity should be under $0.6 \mathrm{~cm} / h^{1 / 2}$. This was defined to be the value at which, in a 24-hour rain, water would penetrate concrete to a depth of $30 \mathrm{~mm}$, i.e., across the entire reinforcement cover. While uncommon, a 24-hour rain is possible in certain places, where the reinforcing steel in concretes with a sorptivity of $0.6 \mathrm{~cm} / \mathrm{h}^{1 / 2}$ or higher would be subject to corrosion. The authors consequently recommended a safety factor of 2 , specifying a design sorptivity value of $0.3 \mathrm{~cm} / \mathrm{h}^{1 / 2}$ to ensure concrete durability. Assuming a mean penetration front of $0.3 \mathrm{~cm} / \mathrm{h}^{1 / 2}$ to be equal to $0.3 \mathrm{~g} / \mathrm{cm}^{2} \mathrm{~h}^{1 / 2}$, the conclusion drawn is that, from the age of three days onward, all the concretes analyzed in this study exhibited sorptivity values lower than the limit stipulated by Ho et al.

They behaved differently, however, when humid curing was interrupted prematurely. Table 2 compares 28-day sorptivity for concretes made with ternary blended cements and concretes cured under humid conditions throughout (28 days).

Tabla 2 / Table 2

Capacidad de absorción relativa al hormigón con curado $\mathrm{D}$ a 28 días

Comparison of sorptivity in concretes cured under different conditions

\begin{tabular}{|c|c|c|c|c|}
\hline Muestra & $\begin{array}{c}24 \text { h en moldes y } 28 \\
\text { días al aire (Curado A) } \\
24 \text { h in moulds, air-cured } \\
\text { for } 28 \text { days }(A)\end{array}$ & $\begin{array}{c}24 \text { h en moldes, } 2 \text { días } \\
\text { en agua y } 25 \text { días } \\
\text { al aire (Curado B) } \\
24 \text { h in moulds, immersed in water } \\
\text { for } 2 \text { days and air-cured for } 25 \text { (B) }\end{array}$ & $\begin{array}{c}\text { 24h en moldes, } 6 \text { días } \\
\text { en agua y } 21 \text { días al } \\
\text { (Curado C) } \\
24 \text { h in moulds, immersed in water } \\
\text { for } 6 \text { days and air-cured for } 21 \text { (C) }\end{array}$ & $\begin{array}{c}24 \mathrm{~h} \text { en moldes y } 28 \text { días } \\
\text { en agua }\left(20 \pm 2^{\circ} \mathrm{C}\right) \\
\text { (Curado } \mathrm{D}) \\
24 \mathrm{~h} \text { in moulds, immersed in water } \\
\text { for } 28 \text { days }\left(20 \pm 2^{\circ} \mathrm{C}\right)(\mathrm{D})\end{array}$ \\
\hline CPN & 387 & 269 & 198 & 100 \\
\hline $\mathrm{CP} 12 \mathrm{~F}+10$ & 440 & 300 & 254 & 100 \\
\hline $\mathrm{CP} 12 \mathrm{~F}+20$ & 466 & 292 & 231 & 100 \\
\hline $\mathrm{CP} 18 \mathrm{~F}+20$ & 430 & 326 & 292 & 100 \\
\hline
\end{tabular}

El curado al aire se realizó en ambiente de laboratorio. / Specimens were air-cured in the laboratory. 


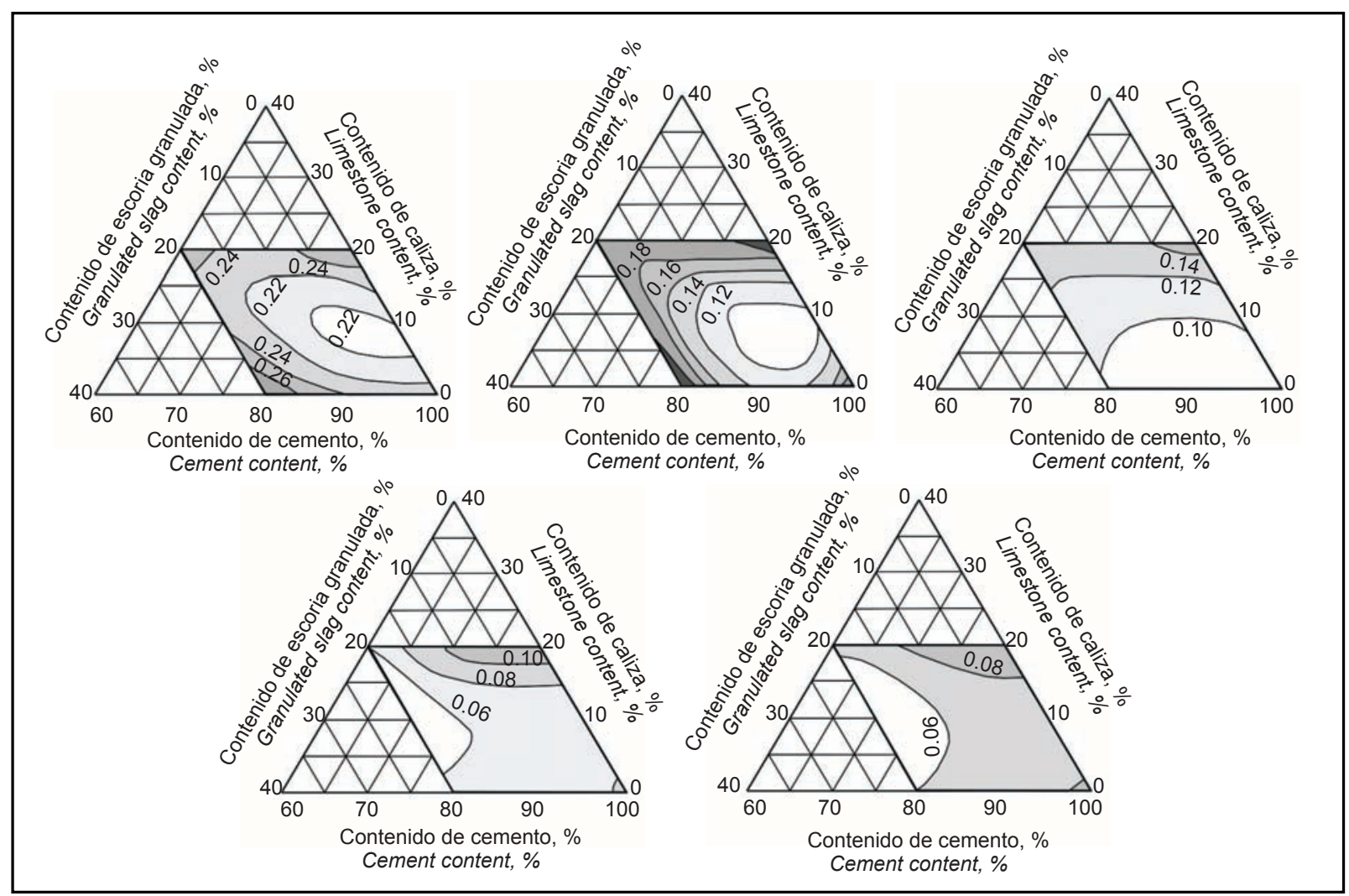

Figura 4. Curvas de isorrespuesta de la capacidad de absorción ( $\left.\mathrm{g} / \mathrm{cm}^{2} \mathrm{~h}^{1 / 2}\right)$ : a) 3 días, b) 7 días, c) 28 días, d) 90 días y e) 360 días. Figure 4. Sorptivity $\left(\mathrm{g} / \mathrm{cm}^{2} \mathrm{~h}^{1 / 2}\right)$ iso-response contours at a) 3 days, b) 7 days, c) 28 days, d) 90 days and e) 360 days.

En ella se puede observar que frente a la interrupción del curado húmedo, la capacidad de absorción de los hormigones con cemento ternario presenta un incremento drástico con respecto al curado húmedo. La máxima diferencia de la capacidad de absorción entre el curado $A$ y $D$ es de $466 \%$ para el hormigón con $C P 12 F+20 E$. Por otra parte, el aumento de este parámetro en el hormigón con $C P N$ resulta menor (387\%) a los alcanzados por los hormigones con cementos ternarios.

\section{DISCUSIÓN}

Los resultados obtenidos bajo curado húmedo continuo pueden justificarse a partir de la modificación en la hidratación, la porosidad y la estructura de poros que producen las adiciones minerales estudiadas. En trabajos previos se ha demostrado $(9,10)$ que el agua no evaporable aumenta a medida que crece el contenido de caliza en el cemento binario y que este incremento es muy importante a los 28 días. A edades más avanzadas, el progreso de la hidratación del clínker Portland tiende a minimizar esta ventaja y el efecto de dilución es preponderante. La adición de escoria también produce un efecto filler positivo $(9,11)$, pero, de acuerdo al contenido de escoria incorporado, el efecto de la dilución de los granos
The data tabled show that when humid curing was interrupted, ternary cement concrete sorptivity rose drastically compared to the values recorded for specimens continuously cured under humid conditions. The maximum difference in sorptivity between curing conditions $A$ and $D$ was $466 \%$, recorded for $C P 12 F+20 E$ concrete. Moreover, sorptivity rose less in CPN (387\%) than in ternary cement concretes under these conditions.

\section{DISCUSSION}

The results obtained for specimens continuously cured under humid conditions can be explained by the changes in hydration, porosity and pore structure brought about by the mineral additions studied. Prior research $(9,10)$ showed that non-evaporable water increases with limestone content in binary cement, particularly in 28-day specimens. At later ages, Portland clinker hydration progress tends to minimize this advantage and the dilution effect prevails. Although slag also prompts a filler effect $(9,11)$, depending on the content of this component, cement particle dilution may prevail at early ages before the slag begins to react. This occurs after the seventh day, when the CSH formed as a result of the 
de cemento en las primeras edades puede ser más importante, porque la escoria aún no ha reaccionado. Después de 7 días, la escoria reacciona formando $\mathrm{CSH}$ que aumenta la cantidad de agua no evaporable. Finalmente, el elevado grado de hidratación causado principalmente por la caliza puede compensar el efecto de dilución durante las primeras edades. Debido a esto, los hormigones elaborados con hasta $10 \%$ de caliza y $10 \%$ de escoria tienden a registrar los valores más bajos de absorción.

Sin embargo, cuando se reemplaza cemento Portland por caliza, el mayor grado de hidratación alcanzado no implica un aumento en el volumen de productos de hidratación debido a que con la incorporación de esta adición no se generan productos de hidratación con características cementantes (12). También, debido a que la reacción de la escoria es diferida en el tiempo, en el sistema se produce un aumento de la relación a/c efectiva (menor cantidad de material inicialmente reactivo) que es atribuible para todas las edades a la incorporación de caliza y a la inclusión de escoria sólo para edades tempranas. En consecuencia, los hormigones con cemento ternario con alto contenido de caliza y escoria alcanzan en las primeras edades los mayores valores de absorción.

Por otra parte, la permeabilidad del hormigón puede reducirse cuando se produce la segmentación de la estructura de poros. De acuerdo a Powers (13), el tiempo para producir este proceso depende de la relación $a / c$ y del grado de hidratación $(\alpha)$ desarrollado en el cemento. Para que ocurra este proceso cuando la relación $a / c$ efectiva es de 0,50, 0,57 y 0,61, el $\alpha$ estimado de acuerdo al modelo de Powers es de 70, 81 y $91 \%$, respectivamente. Según esto, el tiempo estimado para alcanzar la segmentación de los poros en el hormigón con $C P N$ (a/c efectiva: 0,50$)$ y en el hormigón con $\operatorname{CP12F}(a / c$ efectiva: 0,57 ) es de 28 días, mientras que en el hormigón con CP18F (a/c efectiva: 0,61 ) es de 35 días. Sin embargo, la presencia de la caliza diseminada en la pasta puede modificar la conectividad y tortuosidad de la red de capilares, incrementando la porosidad total y produciendo un corrimiento hacia tamaños de poros más grandes (14). Simultáneamente, con el avance de la hidratación, la escoria reacciona generando principalmente $\mathrm{CSH}$, que produce el refinamiento de poros en la pasta de cemento y provoca un corrimiento del tamaño de poros hacia poros más pequeños (15). En función de lo expuesto, a edades avanzadas, los menores valores de absorción se obtienen en los hormigones elaborados con cementos ternarios con bajos contenidos de caliza y alto contenido de escoria.

Por último, frente a la interrupción temprana del curado húmedo se producen importantes aumentos en la capacidad de absorción de los hormigones elaborados con reaction raises the amount of non-evaporable water. Finally, the high degree of hydration resulting primarily from the presence of limestone may offset the dilution effect at early ages. For this reason, concrete made with up to $10 \%$ limestone and $10 \%$ slag tends to exhibit lower absorption values.

Nonetheless, when Portland cement is replaced by limestone, the higher degree of hydration reached does not entail a rise in hydration product volume, for the inclusion of this addition does not generate cementitious hydration products (12). Similarly, since the slag reaction is deferred, the system undergoes an effective increase in the $w / c$ ratio (due to the initially smaller amount of reactive material) which is attributable to the presence of limestone and slag, the former at all ages and the latter in the early ages only. Consequently, concretes made with a ternary cement containing high proportions of limestone and slag show the highest absorption values at early ages.

Concrete permeability may be lowered, however, when the pore structure is segmented. According to Powers (13), the time required for this to occur depends on the $w / c$ ratio and the degree of hydration $(\alpha)$. With effective $w / c$ ratios of $0.50,0.57$ and 0.61 , the a value required for this process to take place according to the Powers model is 70, 81 and 91\%, respectively. Further to these data, the estimated time needed for pore segmentation in CPN concrete (effective w/c: 0.50) and CP12F concrete (effective w/c ratio: 0.57 ) is 28 days, but comes to 35 days in CP18F concrete (effective $\mathrm{w} / \mathrm{C}$ ratio: 0.61). The presence of limestone in the paste may, however, modify the connectivity and intricacy of the capillary network, raising total porosity and prompting a shift toward larger size pores (14). At the same time, as hydration progresses, the slag reacts primarily by generating $\mathrm{CSH}$, which leads to a refinement of the pores in the cement paste and a shift to smaller pore sizes (15). It follows from the foregoing that the smallest absorption values obtained at later ages are found in concretes made with ternary cements having low limestone and high slag contents.

Lastly, when humid curing is interrupted prematurely, sorptivity increases substantially in CPN and ternary blend cement concretes both (see Table 2). Seven 
CPN y con cementos compuestos ternarios (Tabla 2). Un curado húmedo de 7 días (curado $C$ ) no parece ser un tiempo de curado húmedo adecuado para el hormigón con $C P N$, pues el grado de hidratación alcanzado por este hormigón a 28 días cuando se encuentra sometido a un curado $C$ es de sólo $64 \%$, y este valor resulta menor al estimado en el modelo de Powers (70\%) en consecuencia a esta edad aún no se ha alcanzado la segmentación de la red de poros (15). Los tiempos para alcanzar la segmentación de poros con cementos ternarios deberá ser aún mayor considerando que la caliza no produce $\mathrm{CSH}$ y que la escoria necesita de la presencia de agua para continuar hidratándose. Por lo tanto, para disminuir el ingreso de sustancias agresivas al interior del hormigón con cemento Portland sin adición o cemento ternario es necesario aumentar el tiempo de curado húmedo por encima de los 7 días.

Por otra parte, en experiencias anteriores (16) se ha observado que a medida que aumenta el contenido de caliza en el cemento, disminuye la resistencia a la penetración de cloruros en el hormigón. Pues, a pesar de que con el incremento de esta adición aumenta el grado de hidratación del cemento, esto no se traduce en una mayor cantidad de $\mathrm{CSH}$, se produce un aumento de la relación a/c efectiva y también en la permeabilidad del hormigón. Adicionalmente, se ha demostrado que el empleo de escoria en el hormigón bloquea los cloruros en la región superficial del mismo y a pocos milímetros de la superficie, el perfil de cloruros alcanza valores despreciables. Este comportamiento es atribuido a que la reacción de la escoria permite la obtención de una microestructura más compacta de la matriz, al aumento de la compacidad de la interfase matriz-agregado y una significativa reducción de poros capilares (17-18). En estudios previos realizados en hormigones (elaborados con los mismos materiales y proporciones que en el presente trabajo) sobre el frente de penetración de cloruros se ha determinado que, cuando los hormigones son curados en forma apropiada (curado húmedo mínimo de 7 días), la utilización de bajo contenido de caliza (hasta aproximadamente 12\%) y mayores contenidos de escoria en el cemento ternario permite obtener un hormigón con similar o mejor resistencia a la penetración de cloruros que el registrado por el hormigón con CPN (Tabla 3), debido al aumento en la hidratación y a la menor capacidad de absorción que produce la acción conjunta de las adiciones (19).

Sin embargo, estos estudios (19) también mostraron que frente a un curado deficiente (1 día de curado húmedo), este comportamiento se revierte (Tabla 4), y esto es atribuido a la menor reacción de la escoria que produce un aumento en la porosidad del hormigón y un incremento en el tamaño de poros (20).

Por último, para materializar hormigones durables elaborados con cementos compuestos ternarios; en la práctica, es recomendable aumentar el recubrimiento de las days of humid curing (curing conditions $C$ ) do not appear to be suitable for CPN concrete, for under such conditions the 28-day degree of hydration is only 64\%, which is lower than the value estimated in the Powers model (70\%). In other words, the pore network is not fully segmented at this age (15). The time required to reach pore segmentation with ternary cements should be even greater, inasmuch as limestone generates no $\mathrm{CSH}$ and water is required for slag hydration to continue. Therefore, both unadditioned Portland and ternary cement concrete require humid curing times longer than seven days to reduce the inflow of aggressive substances.

Moreover, prior research (16) found that as cement limestone content grows, concrete chloride resistance declines. Indeed, not only does the rise in cement hydration with increasing amounts of this addition fail to translate into larger volumes of $\mathrm{CSH}$, it generates a higher effective $w / c$ ratio and raises concrete permeability. The use of slag in concrete, in turn, has been shown to block chlorides on or within a few millimetres of the surface. The result is a chloride profile with negligible values. This behaviour is attributed to the appearance of a matrix with a more compact microstructure as a result of the slag reaction, the increased compactness of the matrix-aggregate interface and a significant reduction in capillary porosity (17-18). Prior research on chloride penetration in concrete (made with the same materials and in the same proportions as in the present study) showed that when appropriately cured (at least seven days under humid conditions), the use of a ternary cement with a low limestone content (up to approximately 12\%) and higher percentages of slag, yields a concrete whose chloride penetration resistance is similar to or higher than the levels observed in CPN concrete (Table 3). This was attributed to the increased hydration and lower sorptivity generated by the joint action of the two additions (19).

Nonetheless, no such behaviour was observed (19) when concrete curing was deficient (one day of humid curing) (Table 4), for the lower degree of slag reaction led to an increase in concrete porosity and pore size (20).

Lastly, to ensure the durability, in practice, of ternary blend cement concrete, the reinforcement cover should be deepened and humid curing time lengthened 
Tabla 3 / Table 3

Penetración de cloruros a 180 días de inmersión en una solución de $\mathrm{NaCl}$ al $3 \%$ de hormigones curados de 7 días en agua saturada con cal y 21 días en ambiente de laboratorio Chloride penetration after 180-day immersion in a 3\% NaCl solution in concretes cured for seven days in lime-saturated water and 21 days in a laboratory atmosphere

\begin{tabular}{|c|c|c|c|}
\hline \multirow{2}{*}{$\begin{array}{l}\text { Profundidad } \\
\text { de penetración, } \mathbf{m m} \\
\text { Penetration depth, } \mathrm{mm}\end{array}$} & \multicolumn{3}{|c|}{$\begin{array}{c}\text { Contenido de } \mathrm{Cl}^{-}, \mathrm{kg} \mathrm{Cl}^{-} / \mathrm{m}^{3} \text { de hormigón } \\
\mathrm{Cr} \text { content, } \mathrm{kg} \mathrm{Cr} / \mathrm{m}^{3} \text { of concrete }\end{array}$} \\
\hline & CPN & CP18F & $\mathrm{CP} 12 \mathrm{~F}+20 \mathrm{E}$ \\
\hline 5 & 3,90 & 3,92 & 3,95 \\
\hline 15 & 3,35 & 3,89 & 3,25 \\
\hline 25 & 1,41 & 3,01 & 1,53 \\
\hline 35 & 0,0 & 1,70 & 0,21 \\
\hline 45 & 0,0 & 0,51 & 0,0 \\
\hline 55 & 0,0 & 0,0 & 0,0 \\
\hline
\end{tabular}

armaduras y el tiempo de curado húmedo del hormigón, para evitar que el agua y/o sustancias agresivas puedan entrar en contacto con las mismas.

\section{CONCLUSIONES}

De las experiencias realizadas, con los materiales seleccionados y las proporciones utilizadas, se puede concluir que:

- El empleo de caliza en el cemento ternario permite aumentar la hidratación temprana del cemento Portland y disminuir la absorción del hormigón, mientras que la escoria reproduce este efecto a edades más avanzadas. Aun así, es necesario limitar la cantidad de caliza incorporado a valores de alrededor del $12 \%$ y asegurar un curado adecuado para minimizar los mecanismos de transporte y evitar el ingreso de iones agresivos al hormigón.
Tabla 4 / Table 4

Penetración de cloruros a 180 días de inmersión en una solución de $\mathrm{NaCl}$ al 3\% de hormigones curados de 1 día en agua saturada con cal y 21 días en ambiente de laboratorio

Chloride penetration after 180-day immersion in a $3 \% \mathrm{NaCl}$ solution in concretes cured for one day in lime-saturated water and 21 days in a laboratory atmosphere

\begin{tabular}{|l|cc|}
\hline \multirow{2}{*}{$\begin{array}{l}\text { Profundidad } \\
\text { de penetración, } \mathbf{~ m m} \\
\text { Penetration depth, } \mathbf{m m}\end{array}$} & $\begin{array}{l}\text { Contenido } \mathrm{de}^{-}, \mathbf{~ k g ~ C l}^{-} / \mathbf{m}^{3} \text { de hormigón } \\
\text { Cl content, } \mathrm{kg} \mathrm{Cl} / \mathrm{m}^{3} \text { of concrete }\end{array}$ \\
\cline { 2 - 3 } $\mathbf{5}$ & $\mathbf{C P N}$ & $\mathbf{C P 1 2 F}+\mathbf{2 0 E}$ \\
\hline $\mathbf{1 5}$ & 3,35 & 3,95 \\
\hline $\mathbf{2 5}$ & 2,02 & 3,90 \\
\hline $\mathbf{3 5}$ & 0,6 & 3,02 \\
\hline $\mathbf{4 5}$ & 0,0 & 1,65 \\
\hline $\mathbf{5 5}$ & 0,0 & 0,55 \\
\hline
\end{tabular}

to prevent water and/or aggressive substances from reaching the steel.

\section{CONCLUSIONS}

The conclusions to be drawn from the results discussed above are as follows:

- The use of limestone in ternary cement enhances early Portland cement hydration and decreases concrete absorption, while the addition of slag achieves these same effects at later ages. Even so, the amount of limestone used must be limited to values of around $12 \%$ and curing times must be sufficient to minimize transport mechanisms and prevent the inflow of aggressive ions into the concrete.

\section{BIBLIOGRAFÍA / BIBLIOGRAPHY}

(1) Gopalan, M. K.: "Sorptivity of fly ash concretes", Cement and Concrete Research, vol. 26, 8 (1996), pp. 1189-1197.

(2) Camarini, G.; Balayssac, J. P. y Detriché, Ch. H.: "Influence of cement type and curing conditions on initial absorption of concrete", Proc. $2^{\circ}$ CANMET/ACI, ACI SP-186, Gramado, Brazil (1999), pp. 427-431.

(3) Menéndez, G.; Bonavetti, V. L. e Irassar, E. F.: "Hormigones con cementos compuestos ternarios. Parte I: Estado fresco y propiedades mecánicas", Materiales de Construcción, vol. 56, nº 284 (2006), pp. 56-57.

(4) Martys, N. S. y Ferraris, C.F.: "Capillary transport in mortars and concrete", Cement and Concrete Research, vol. 27,5 (1997), pp. 747-760.

(5) Menéndez, G.; Bonavetti, V. L. e Irassar, E. F.: "Tasa de Absorción en Hormigones con Cemento Compuesto", Hormigón, 38 (2002), pp. 25-34.

(6) Montgomery, D. C.: "Diseño y análisis de experimentos". Grupo Editorial Iberoamérica, México, 1998.

(7) Dhir, R. K. y Mc Carthy, M. J.: "Concrete cover: Role in achievement of in service durability", $1^{\circ}$ Congreso Internacional de Tecnología del Hormigón, AATH. (1998) Buenos Aires, Argentina.

(8) Ho, D. W. S.; Hinczak, I.; Conroy, J. J. y Lewis, R. K.: "Influence of slag cement on the water sorptivity of concrete", Proc. Fly ash, silica fume, slag and natural puzzolans in Concrete. ACI SP 91-72, Madrid, España, 1986, pp. 1463-1473.

(9) Menéndez, G.; Bonavetti, V. L. e Irassar, E. F.: "Strength development of ternary blended cement with limestone filler and blast-furnace slag", Cement and Concrete Composites, vol. 25, 1 (2003), pp. 57-63. 
(10) Carrasco, M. F.; Menéndez, G.; Bonavetti, V. L. e Irassar, E. F.: "Strength Optimization of "Tailor Made Cement" with Limestone Filler and Blast Furnace Slag", Cement and Concrete Research, vol. 35, 7 (2005), pp. 1324-1331.

(11) Zhang, C.; Wang, A.; Tang, M. y Liu, X.: "The filling role of pozzolanic material", Cement and Concrete Research, vol. 26, 6 (1996), pp. 943-947.

(12) Sersale, K.: "Advances in Portland and Blended Cement", Proc. 9th International Congress of the Chemistry of Cement, New Delhi, India, vol. I (1992), pp. 277-279.

(13) Powers, T. C.; Copeland, L. E. y Mann, H. M.: "Capillary continuity or discontinuity in cement paste", Journal Portland Cement Assoc. Res. Devel. Labs, mayo (1959), pp. 38-48.

(14) Hornain, H.; Marchand, J.; Duhot, V. y Regourd, M.: "Diffusion of chloride ions in limestone filler blended cement pastes and mortars", Cement and Concrete Research, vol. 8, 25 (1995), pp. 1667-1678.

(15) ACI 233. "Ground Granulated Blast-Furnace Slag as a Cementitious Constituent in Concrete", ACI Manual of Concrete Practice. Part 1. Materials and General Properties of Concrete, 1998.

(16) Bonavetti, V.L.; Donza, H.; Rahhal, V. e Irassar, E. F.: "Influence of initial curing on properties of concrete containing limestone blended cement", Cement and Concrete Research, 30 (2000), pp. 703-708.

(17) Mohammed, T.; Yamaji, T. y Hamada, H.: "Chloride diffusion, microstructure, and mineralogy of concrete after 15 years of exposure in tidal environment", ACI Materials Journal, vol. 99, 3 (2002), pp. 256-263.

(18) Alexander, M. G. y Magee, B. J.: "Durability performance of concrete containing condensed silica fume", Cement and Concrete Research, vol. 29, 6 (1999), pp. 917-922.

(19) Bonavetti, V. L.; Irassar, E. F.; Menéndez, G.; Carrasco, M. F. y Donza, H.: "Durabilidad de hormigones elaborados con cementos binarios y ternarios. El Hormigón Estructural y el Transcurso del Tiempo", Simposio FIB, La plata Argentina, vol. 1 (2005), pp. 201-208. (20) Ramezanianpour, A. A. y Malhotra, V. M.: "Effect of curing on the compressive strength, resistance to chloride-ion penetration and porosity of concretes incorporating slag, fly ash or silica fume", Cement and Concrete Composite, vol. 17, 2 (1995), pp. 125-133. 